\title{
Participants' productive disruption of a community photo-elicitation project: improvised methodologies in practice
}

\section{Katy Vigurs \& Helen Kara}

To cite this article: Katy Vigurs \& Helen Kara (2017) Participants' productive disruption of a community photo-elicitation project: improvised methodologies in practice, International Journal of Social Research Methodology, 20:5, 513-523, DOI: 10.1080/13645579.2016.1221259

To link to this article: https://doi.org/10.1080/13645579.2016.1221259

曲 Published online: 23 Aug 2016.

Submit your article to this journal $\pi$

Џلll Article views: 268

Q View related articles $\asymp$

View Crossmark data 


\title{
Participants' productive disruption of a community photo- elicitation project: improvised methodologies in practice
}

\author{
Katy Vigurs ${ }^{a}$ and Helen Kara ${ }^{b}$ \\ aSchool of Education, Staffordshire University, Stoke-on-Trent, UK; bWe Research It Ltd, Uttoxeter, UK
}

\begin{abstract}
This article reports on an attempt to use photo-elicitation to explore contested intergenerational perceptions and experiences of 'place' in one English village. Participants actively disrupted the photo-elicitation project and ended up co-creating an enriched research design that allowed them to represent how they experienced 'place'. The spontaneous, mixed mediaelicitation that resulted overturns some of the more straightforward notions that are aligned with photo-elicitation techniques. This article builds on a growing body of critical literature on photo-elicitation and shows how participants' disruption of a project's research methods can be both challenging and fruitful in practice. The researcher's flexibility and willingness to work with participants' alternative approaches proved extremely effective in allowing participants to communicate their'imagined geographies' and to identify experiences of social inequality. This article explores how the initially problematic in participant involvement can be turned into the productive through the use of 'improvised methodologies'.
\end{abstract}

\section{ARTICLE HISTORY}

Received 29 July 2015

Accepted 3 August 2016

\section{KEYWORDS}

Photo-elicitation; participatory research; community research; place; improvised methodologies

\section{Introduction}

This article charts the challenges and unexpected outcomes that can sometimes occur when designing and conducting participative research. Of course, disruption of the research process can occur in many ways and has long been acknowledged (Jordan, Redley, \& James, 1994), but here we build specifically on a growing body of critical literature on photo-elicitation (e.g. Gallagher, 2006; Hunleth, 2011; Luttrell, 2000, 2010, 2013; Mannay, 2015; Nind, Boorman, \& Clarke, 2012). This article shows how research participants' disruption of a photo-elicitation project can be both challenging and fruitful in practice. For example, in this case, the researcher's flexibility and willingness to be open to and work with participants' alternative approaches proved extremely effective in enabling participants to communicate their 'imagined geographies' (Massey \& Jess, 1995) and to identify experiences of social inequality.

Participatory research is focused on communities or groups, and aims for full involvement of participants throughout the research (Bhana, 2006; Chevalier \& Buckles, 2014). Such research is intended to benefit the communities or groups from which the participants are drawn (Wassenaar, 2006) with the aim of empowering disempowered communities, groups and individuals (Bhana, 2006). It also benefits the research: in communities, a participatory approach can 'bring new dimensions and perspectives to research questions' (Goodson \& Phillimore, 2012, p. 3). It often seeks to give participants the opportunity to share their views and influence the research process more fully than most other 
paradigms, particularly at the stage of gathering data. Participant influence at this point, however, can have unexpected consequences for research, as this article demonstrates.

\section{The merits of photo-elicitation techniques}

Using photo-elicitation - the use of photographs as the basis for interviews - is not new in social research (Banks, 2007; Carson et al., 2005; Collier, 1967, 2001; Hammersley \& Atkinson, 2007; Pink, 2007, 2009). Much has been written about the value of using visual methods with children and young people in particular (Bragg \& Buckingham, 2008; Darbyshire, Macdougall, \& Schiller, 2005; Johnson, 2008; Kaplan, 2008; Sorin, Brooks, \& Haring, 2012; Thomson, 2008; White, Bushkin, Carpena-Mendez, \& Laoire, 2010). Such researchers argue that visual methods allow children and young people to provide 'expert testimony about their experiences, associations and lifestyles' (Thomson, 2008, p. 1). Schratz and Steiner-Loffler (2000) claimed that photography gave child participants the opportunity to represent and communicate the 'inner world' of school life as they saw it. Additionally, Purcell (2007) states that taking visual approaches with young people can help to ascertain places where they do and do not go and 'open up discussion about why this is so' (p. 118). And Bradbury-Jones and Taylor, while acknowledging that participatory research with children is not straightforward, argue that 'children as researchers are a powerful conduit for other children's voices' (2015, p. 161). However, Lomax (2012) critiques these views, suggesting that they may over-privilege the knowledge and insights of children, particularly within research that is planned and prioritised by adults. She also suggests that the dynamics between children and other children, and between children and adults, can shape the ways in which children portray their worlds for researchers (Lomax, 2012).

Wang and Burris (1997) suggest that photo-elicitation projects with adults can be a powerful stimulus for data generation because the photographs could document the lived reality of the participants involved. More specifically, Purcell (2007, p. 117) highlights that the use of photo-elicitation approaches with adults about their community can enable people to 'record and reflect their community's strengths and problems', as well as promoting dialogue of issues through the discussion of photographs. Furthermore, Loeffler (2005) argues that photographs can act as 'memory anchors' that assist participants to better reflect upon and explain their perceptions and experiences of particular phenomena. Actively engaging participants in the photographing of their community has been considered by some to be a more powerful tool for eliciting participants' experiences and perceptions than an interview alone (Allen, 2011; Harper, 1998; Kaplan, 2008; Pimlott-Wilson, 2012; Pink, 2007; Purcell, 2007; Rose, 2012; Schratz \& Steiner-Loffler, 2000). It is also thought to be more effective at engaging and retaining the involvement of 'hard-to-reach' participants (Klitzing, 2004; Stedman, 2005), as taking photographs and then discussing them is considered to be less threatening and more interesting for participants than other research tools (Klitzing, 2004; Shohel, 2012).

\section{Using participatory methods to research conflicting narratives of place}

The first author of this article found herself conducting research in a particular place (the village of Broadley) as she had been commissioned to conduct an evaluation of a new learning centre that was being developed by an external partnership organisation, within the village and for 'the community'. However, it was the partnership organisation's unproblematised discourse about the community of Broadley as a singular, coherent and bounded place that prompted her to conduct an additional, participative study with village residents. The idea behind the complementary study was to design a research project that would involve a cross-section of residents to explore contrasting local views of Broadley, and particularly to reveal some of the different ways that residents participate in, use and contribute to the village. It was hoped that this set of local narratives could be used to inform, and possibly challenge, the partnership organisation's construction of Broadley 'the place'.

The term 'place' is often used to refer to a location; it is somewhere that has fixed objective co-ordinates and can be found on a map (Cresswell, 2004). In this sense, the project was located in the 
semi-rural, ex-mining village of Broadley (pseudonym), in the English Midlands. Historically, the area of Broadley was a remote, rural parish. Coal was mined there in the nineteenth and twentieth centuries, although today there is little evidence of the heavy industry that would once have been a prominent feature of the local landscape. Indeed, in the twenty-first century, the parish is widely regarded as a desirable commuter village; being situated both close to a motorway network as well as sustaining the appearance of a traditional English village surrounded by countryside and farmland. However, it is important to note that although places, such as Broadley village, do have official boundaries drawn around them, 'these boundaries do not embody any eternal truth of place' (Massey, 1995, p. 67). Indeed, identities of place are frequently contested (Massey \& Jess, 1995).

\section{Introduction to the intended photo-elicitation project}

The study with Broadley residents sought to conduct qualitative research with three community groups, to better understand how residents themselves perceived and experienced issues of place and community. This article describes how two of the community groups actively disrupted the photo-elicitation project, and how they ended up co-creating the research design so that it allowed them to better reflect upon and represent how they experienced place and community. This raises some valuable issues, in particular the challenges of planning and conducting a research project with a diverse sample in one geographic place, and how the initially perplexing in terms of participant involvement can be turned into the productive.

A participant-driven approach to the photographing of their village was planned to try to partially shift control over data generation from the researcher to the participants, through 'creating opportunities for citizens to be more meaningfully involved' (Van Auken, Frisvoll, \& Stewart, 2010, p. 375). Such an approach, in contrast to externally driven photo-elicitation, can be viewed as a relatively open-ended and bottom-up research strategy, as researchers have little control over the selection of the images photographed. However, it should be acknowledged that in this study the initial focus for the photo-elicitation project was set by the researcher, so although the participants were free to take whatever photographs they liked around the village, they were still following someone else's agenda (Purcell, 2007).

The study's original design aimed to task participants with the production of images of their village, around which a group interview would be structured (Kaplan, 2008; Purcell, 2007; Schratz \& Steiner-Loffler, 2000). Knowing that Broadley participants of different generations were likely to be involved, the researcher wanted to design an approach that would enable each group to participate as fully as possible. The intention was that the act of photography by participants and the interactive interpretation of the photographs through group discussion would facilitate the participants' telling and re-telling of stories of place in both the past and the present (Aull Davies, 2008;Garro, 2000; Middleton \& Edwards, 1990; Radley \& Taylor, 2003a, 2003b).

Photographs do not have a meaning independent of the contexts in which they are produced and understood (Wells, 2000). Instead they should be regarded as 'visual fragments of particular engagements' (Radley \& Taylor, 2003b, p. 130) between a participant and his/her local place, but which the participant needs to explain to the researcher and discuss with others in the group. In the intended photo-elicitation project, the aim was to understand what the groups had chosen to make visible in relation to place and to explore their reasons for that during the group interviews. As Harper (2002, p. 23) suggests, collaborative knowledge can be produced when a group of people discuss the meaning of photographs as they become engaged in trying to 'figure something out together'. The researcher hoped that she would hear not only individuals' explanations of the images of place they had produced, but also the groups' discussions of place stimulated by the sharing of the photographs and accompanying narratives.

In this sense, she was not overly concerned about the apparent 'stillness' of photographs (Collier, 2001) nor photographs being seen as temporally produced artefacts (Banks, 2007). This was because the act of participants photographing their view of village life, together with the photographs produced, 
were intended to act as triggers for narratives of place. Thus, the intention was never to analyse the photographs. Indeed, the researcher was less interested in the contents of the photographs and more concerned to listen to the reasons the images were taken and what they represented about place to the participants. She then planned to carry out an inductive analysis of data generated through three group interviews.

\section{Gaining access to Broadley participants}

Established local groups were targeted. A list of community groups was compiled from both parish noticeboards and a directory held at the village library. From this, three community groups were selected to ensure a mix of ages, gender and social backgrounds. The researcher chose to work discretely with each group, as it was felt that participants would be happier sharing and discussing issues of place within their regular social groups (Gaskell, 2002; Gerson \& Horowitz, 2002). For example, Rose (1995) warns that senses of place between individuals and groups living in the same local area are often not only different, but also frequently part of unequal social relations. Thus, it appeared more ethical to bound the dialogue about place within each pre-existing group, although this may have naively assumed that there would not be unequal social relations within the pre-existing groups.

To this end, fieldwork was conducted with Broadley Ladies' Choir, Broadley Running Club and Broadley Youth Bus (a mobile youth project taking place in the parish) over a period of six months. The Ladies' Choir sample comprised eight White British, female participants aged between 74 and 87 years old. The majority were born in the parish and had long-standing ancestral connections to the place. Those that had moved into the parish had now been living in Broadley for over 50 years. The Running Club sample included six White British males and three White British females aged between 23 and 60 years old. All but the youngest member of the Running Club had migrated into the parish as adults. The majority had lived in the village between 10 and 25 years. The Youth Bus sample was made up of four White British males aged between 13 and 14. They all attended the local secondary school in the parish. Three had been born and raised in the parish, whilst one had moved into the area five years previously. Written informed consent was obtained from each participant, including parental consent for the teenage Youth Bus participants.

Three meetings were held with each group. The meetings with the Ladies' Choir were held in the community centre where choir practice took place. The meetings with the Running Club were conducted in the cricket club function room where they met for a drink after their runs, and the meetings with the Youth Bus were held on the mobile youth centre where the young people met each week. All meetings were planned to take place straight after each group's regular social activity to minimise any inconvenience for participants. In advance of meeting the groups for the first time, the researcher had designed a photo-elicitation project to be carried out with each group, which was entitled 'Picturing your community'. Time was built in at the first meeting with each group to introduce the research brief and hand out the photo-elicitation packs (information sheet, consent form, researcher contact details, disposable camera and notebook), and also to listen to and discuss participants' initial ideas, queries and concerns. The participants in each group were asked to photograph up to 27 images that represented how they saw and experienced their community, jotting down their reasons for each shot in the notebook if they wished.

Participants were not accompanied during the image production process, as this may have been restrictive in relation to what they felt they should and should not photograph (Pink, 2007). Also, it would have been time-consuming and logistically problematic to accompany 21 individuals. Arrangements were made with each group to collect the cameras after one month, so that the films could be processed and sets of photographs developed. Then a third meeting with each group was organised to conduct an in-depth group interview about the participants' perceptions and experiences of Broadley the place, using their photographs as elicitation material. 


\section{What went 'wrong'? The photo-elicitation project in practice}

All three groups initially expressed high levels of interest in and enthusiasm for the photo-elicitation project. They seemed excited to reflect upon how they perceived and experienced their local community, to capture images that represented these and to then communicate about this with one another and the researcher. At the first meeting with the Running Club, participants eagerly took a photo-elicitation pack each. They conveyed no concerns about carrying out the task and no one made contact with any queries between the first meeting and the date arranged to collect the cameras. A month later, nine cameras were collected with all exposures taken.

The Ladies' Choir was the first group to directly challenge aspects of the photo-elicitation project. It began with a participant telephoning the researcher to say she was having problems with the disposable camera. She said she was unfamiliar with cameras and that her hands shook when she took a photograph, which meant she was both worried that the first few images would be blurred and that she would not be able to take all 27 exposures. She then went on to express that although she had her project 'worked out in [her] head', she had not written anything down in the notebook and was concerned that the researcher would be cross. The researcher talked her through how to use the camera and tried to reassure her that it was not the quality or quantity of images that mattered, but rather the content of them and her reasons for that. This participant was also reminded that making notes in the notebook was optional. However, she was clearly bothered by the quality of the photographs, especially as she knew others in the choir group might see them. She seemed preoccupied with completing the project 'correctly', which suggested that the relative restrictiveness of the brief's method may have been somewhat paralysing in practice for this participant. This was something that had not been considered in the design of the activity.

This prompted the researcher to contact the other seven participants in the Ladies' Choir to see how they were managing with the photo-elicitation project. Only one had confidently taken over 10 images of local places that were meaningful and important to her. The other six were all experiencing a host of issues and barriers with the act of photography itself. These ranged from illness ('I had terrible tooth ache and felt really poorly, so I couldn't leave the house') to mobility issues ('I wanted to take pictures all over the village but I'm not very steady on my feet and I don't have a car'), from a lack of confidence over what to take picture of ('at our age we are not involved in many organisations or daily activities, so there's not much of interest to photograph') to concern that the images they took would mark them out as 'outsiders' to the rest of the group ('I wasn't born in the village like the others, I won't have as many things that I can take pictures of'). At this stage explicit checks were made as to whether the Ladies' Choir participants were wishing to withdraw from the project. However, they all said they wanted to remain involved. Reassurance was offered to participants that there was no 'correct' way to complete the project and they were encouraged to take as many photographs as possible that represented how they saw and felt about the village. The telephone calls seemed to reassure them and everyone agreed to continue with the photo-elicitation project.

The Youth Bus was part of the County Council's youth work provision, which meant that two detached youth workers accompanied the researcher when conducting fieldwork with the Youth Bus participants. Initially, it was considered that this arrangement strengthened the ethical approach to the research with the young people. However, after the first meeting with the young people, the youth workers expressed professional concerns over the ethics of using cameras with young people to collect data about place and space. The young people themselves had reacted positively and with enthusiasm when the photo-elicitation brief was introduced and immediately started to discuss their different ideas, but the youth workers' concerns meant that the researcher was summoned to a meeting at the County Council the next day to discuss whether the photo-elicitation project could go ahead. At this meeting assurances were given to the Youth and Community Education team that parental consent forms had been completed by each young participant's family, that images produced would not be displayed in public or shared with the other research groups, and that the researcher would not meet with the young people without a qualified youth worker being present. On this basis the research was allowed to proceed. 


\section{Disrupting the photo-elicitation project: alternative approaches by two groups}

Although some issues had arisen regarding the conduct of the photo-elicitation brief for both the Ladies' Choir and the youth workers attached to the Youth Bus, these appeared to have been solved. Therefore, in theory, cameras should have been collected from each group for processing, prior to the group interviews. Indeed, out of the 21 cameras disseminated to participants, 20 were collected (one of the Ladies' Choir did not take any photographs), which could have been considered an initial success. However, on picking up the developed photographs it became clear that most of the Ladies' Choir participants had only taken between four and six photographs each. Whereas the Youth Bus participants had each used the whole film, but it was obvious that the images from all four cameras had been taken at the same moment in time in the same space and comprised mainly of close-up images of other participants. This led to concern about the extent to which the photographs produced by the Ladies' Choir and the Youth Bus would effectively elicit their perspectives and experiences of local place during the group interviews. However, this article now moves to explore how the participants went on to adapt, unprompted, the photo-elicitation brief, either by bringing additional artefacts and images to the group interviews, or improvising ways to represent their places, which enabled them to discuss in great depth what place meant to them.

The Ladies' Choir participants chose to supplement the images produced for the project with the following: old photographs of events (carnivals, weddings, theatre productions) and landmarks in the village; old and new newspaper cuttings about significant events or local issues; hand-drawn and photocopied maps of the area with personal annotations added, and long written narratives about their perceptions and experiences of places in the village and how these have changed over time. Five of the choir participants felt that the photo-elicitation project as set by the researcher restricted them to representing what place meant to them in the present day only, which for many was a source of sadness as they felt their world had grown smaller in old age. Instead they elected to bring in artefacts and images that allowed them to remember what place had meant to them in the past, how they had once used the village and to reflect upon the changes that have occurred. Their spontaneous adaptation of the research brief meant that the group interview produced lively and detailed recall, which resulted in the generation of rich and deep data about their conceptions of place and belonging over their lifetimes. After the group interview, a number of the participants made contact by phone or letter to say that they had valued taking part in the research. One said participation in the project had allowed her to develop a voice to share alternative, sometimes negative, experiences of village life and to gently challenge the dominant experiences of others in the group. This suggests that to some extent, the project had not just revealed competing constructions of place, but had created the opportunity for processes of contestation to take place constructively (Rose, 1995). Thus, on a small scale, these processes potentially shifted unequal power-geometries of relations and the structuring of place through such relations (Massey, 2005). Another participant wrote, 'I ended up thoroughly enjoying the project, despite my wobbles in the early days. Writing you a story about my life in the village and taking some photographs has brought back a lot of memories, some of which I had forgotten. I can now share these with my grandchildren. Thank you for helping me to begin this process.'

The Youth Bus participants disrupted the photo-elicitation project in a different way to the Ladies' Choir. It has already been mentioned that they took photographs as a group and at one moment in time, which did not appear to depict many experiences of place. Once this had been confirmed in the group interview and discussion of the photographs exhausted, the young people were asked if they wanted to say anything else about what being 'out and about' in the village looked like from their point of view; something which they had not captured through their photographs. At this point, one of them asked if the researcher had a map of the village (which she did). The group then spent $2 \mathrm{~h}$ using the map to trace their regular movements through the village, pausing at regular intervals to name and explain the places where they 'hung out' and those they were scared of or not yet allowed to frequent.

The young people spontaneously used the map of their village to trace the daily routes they walk as a group. They demonstrated that they were lacking a permanent location in Broadley where they could meet and spend time together as a peer group (pseudonyms have been used): 
Joe:

Will:

Ben:

Will:

Researcher:

Joe:

Gaz:

Researcher:

Joe:

Researcher:

Will:
This is where the 'hard bench' is. That's where we hang out sometimes. And this is where the Fish and Chip shop is where we get our tea most Friday nights. Then this is 'the Club' [Working Men's Club], we go here sometimes on Friday nights, if we're allowed in.

And there's the bus shelter outside the club. We go there sometimes if it's raining.

If you walk in the club with an adult you usually get away with it.

But if we go in, like five or six of us, it's like as soon as you step in someone shouts 'OUT!'

And then what do you do?

We just go to one of our other spots.

We could write down all the streets we walk round if you like.

Is that a positive or a negative thing that you have to walk around?

Neither really.

So it isn't a bad thing when you get moved on from somewhere?

No, not really. We just move on to one of our other places.

In the original conception of the photo-elicitation project it was intended that the young people would have taken pictures of the 'hard bench', the Fish and Chip shop, 'the Club' and the bus shelter. However, this is not what the young people chose to photograph. If there had been no willingness to adapt the methods in situ with the young people, it is likely that their narratives of movement within a local place would not have been explored. As with the Ladies' Choir, the young people's disruption of the photo-elicitation project was not detrimental to the research brief. Indeed, the spontaneous use of the map in the group interview generated vivid and rich data about their experiences of space, place and belonging in Broadley.

The Running Club was the only group to complete the photo-elicitation project as it had been set. They had taken the cameras out with them whilst running in and around the village. They discussed how the act of running afforded them a different view of Broadley, which influenced their sense of belonging to the village. The runners used the photographs they had taken to outline how their sense of belonging emerged from the connections they developed between themselves and the physical geography of Broadley:

Tony: Because we run, we see stuff that loads of other locals don't see.

Jim: There's runners and there's people that walk their dogs, they're really the only two groups of people that get out and about in Broadley, rather than just on the streets.

Tony: And that makes a huge difference to how you see Broadley, 'cause before I started running round here, I'd lived here 15 years, but running, you come across the bluebell woods and this kind of stuff ... So there are loads of people in Broadley who wouldn't recognise any of that. It'd be foreign to a lot of people round here, and yet it's on the doorstep.

Jill: I love that others don't see the places that we do. That they wouldn't know where to look, even though it's right there.

The photographs they had taken allowed them to discuss as a group how developing a physical and emotional connection to the parish's countryside helped embed a legitimate feeling of belonging to Broadley, and also allowed them to feel they had achieved a hidden advantage over others that lived in the parish. Prominent in their sense of local identity was a belief that they saw and experienced place and space in the locality in ways that others did not.

As presented above, for two of the groups, the research approach ended up shifting from photo-elicitation to co-constructed mixed media-elicitation. The elicitation material offered and drawn upon differed for each group, but this did not impact negatively upon the usefulness of the group interviews. Indeed, each group interview generated rich and relevant data on how place and space in Broadley was experienced by different groups. The photographs, artefacts and images brought to the group interviews transported the researcher into local spaces and places that would have been difficult (the bluebell wood at the bottom of a steep reclaimed quarry) or even impossible (the 1950 church carnival) to enter physically. 


\section{From photo-elicitation to co-created mixed media-elicitation?}

The resulting, spontaneous, mixed media-elicitation that took place contributes to the growing body of literature that challenges some of the more straightforward, uncomplicated notions that are aligned with photo-elicitation techniques (Collier, 1967; Cronin \& Gale, 1996; Radley \& Taylor, 2003a). Ultimately, the approach used was extremely effective in getting participants to communicate their 'imagined geographies' (Massey \& Jess, 1995) of Broadley. Indeed, the data generated worked to disrupt any sense of coherence of Broadley as a closed and settled place. It exposed rather than occluded 'the disruptions inherent in the spatial' (Massey, 2005, p. 109). Participants were encouraged to consider and communicate their own 'activity spaces ... the places where normal daily life is lived' (Massey, 1995, p. 55) in Broadley, and then to discuss these with others. This communication of competing activity spaces in Broadley, within and across the community groups, allowed the researcher and participants to think about the spatial organisation of Broadley and to pinpoint aspects of social inequality within the community. This article explores the merits of a photo-elicitation research strategy for investigating representations of place. It argues that researchers should practice flexibility when conducting participative research as participants' input can enrich research in ways unanticipated by researchers.

The problem with the initial research approach was the participant-driven photograph aspect, rather than the elicitation aspect. The original research design did not sufficiently ensure that the scope of the project matched the level of each group's confidence or capability, which could have negatively affected their participation or engagement with the topic of the research (Strack, Magill, \& McDonagh, 2004). However, the participants' flexibility and responsiveness to adapt the method to suit their purposes allowed the research to become more open and inclusive. This raises questions for researchers about how to decide what might be the best media for effective elicitation in group interviews. On reflection, building discussion with participants about preferred media for elicitation into the planning cycle would be wise, rather than assuming that the researcher knows best.

As it was, the data produced from the three group interviews allowed narratives to develop that both illuminated how the different groups consumed spaces and made sense of how they moved differently within the village as place (Pink, 2009). The mix of artefacts and images allowed the Ladies' Choir participants in particular to show and then verbalise what was important to them about the place and spaces that they make and inhabit. The materials drawn upon offered rich opportunities for reflexive analysis about place and space, for the participants within each group and for the researcher across the groups.

Employing multiple elicitation methods in researching intergenerational experiences of place and space has proved to be a valuable approach, offering complementary insights and understandings that may be difficult to access through reliance on a single researcher-led method of data collection. The collaborative and responsive approach taken by participants in this project contributed greatly to the depth of understanding gained in relation to how place is experienced in one village. The mixed range of images and artefacts drawn upon across the groups provided insight into the participants' inner lives, triggering memories, emotional states and allowing the groups to relive certain experiences in the village. In each group the participants spoke together as they reminisced about particular events (Van Auken et al., 2010). Images and artefacts generated nostalgia within the groups, which prompted rich recollections through the group interview. The research ended up creating routes into understanding how three different local groups inhabited and created their local worlds (Pink, 2009).

Pink (2009) argues that the dominance of the visual method needs disrupting, so as to open up routes to multi-sensorial knowing with participants. In this project, two groups of participants adapted the method for exploring place and space, which opened up routes to discuss how they saw and felt about the village of Broadley. If the researcher had not been open to the participant-led adaptations, there is a strong chance that the group interviews would not have yielded such rich and deep data on place and space. In this sense, her decision to remain open to and willing to work with spontaneous 
participant-driven approaches enabled a partial shift of control over data generation from the researcher to the participants. This arguably created opportunities for the participants to be more meaningfully involved in the research process than the initial photo-elicitation design would have allowed (Van Auken et al., 2010).

\section{Conclusion}

The disruption of planned research methods by participants would, in some paradigms, be construed as 'failure.' However, failure in research can promote creativity (Kara, 2015). In the project described above, the researcher displayed openness and flexibility in the face of a difficult situation, and was rewarded with a new method of co-created mixed-media elicitation. Improvised methodologies differ from traditional methodologies in that they are not something a researcher can set out to use, but something that can benefit research if researchers are able to stay open to the possibility. This method has considerable potential for wider application in future research.

\section{Disclosure statement}

No potential conflict of interest was reported by the authors.

\section{Notes on contributors}

Katy Vigurs is an Associate Professor in Education at Staffordshire University. Her research interests include critical ethnography, visual and participatory methodologies, researcher development, and social justice and education.

Helen Kara is an independent researcher at We Research It Ltd. Her research interests include creative research methods in the social sciences, ethics, social care, health, and the voluntary/third sector.

\section{References}

Allen, L. (2011). 'Picture this': Using photo-methods in research on sexualities and schooling. Qualitative Research, $11,487-504$.

Aull Davies, C. (2008). Reflexive ethnography (2nd ed.). Abingdon: Routledge.

Banks, M. (2007). Using visual data in qualitative research. London: Sage.

Bhana, A. (2006). Participatory action research: A practical guide for realistic radicals. In M. Terre Blanche, K. Durrheim and D. Painter (Eds.). Research in practice: Allied methods for the social sciences (pp. 429-442). Cape Town: University of Cape Town Press.

Bradbury-Jones, C., \& Taylor, J. (2015). Engaging with children as co-researchers: challenges, counter-challenges and solutions. International Journal of Social Research Methodology, 18, 161-173.

Bragg, S., \& Buckingham, D. (2008). 'Scrapbooks' as a resource in media research with young people. In P. Thomson (Ed.), Doing visual research with children and young people (pp. 114-131). Abingdon: Routledge.

Carson, T., Pearson, M., Johnston, I., Mangat, J., Tupper, J., \& Warburton, T. (2005). Semiotic approaches to imagebased research. In B. Somekh \& C. Lewin (Eds.), Research methods in the social sciences (pp. 164-171). London: Sage.

Chevalier, J., \& Buckles, D. (2014). Participatory action research: Theory and methods for engaged inquiry. London: Routledge.

Collier, J. (1967). Visual anthropology: Photography as a research method. New York, NY: Holt, Rinehart and Winston.

Collier, M. (2001). Approaches to analysis in visual anthropology. In T. van Leeuwen \& C. Jewitt (Eds.), Handbook of visual analysis (pp. 35-59). London: Sage.

Cresswell, T. (2004). Place - A short introduction. Oxford: Blackwell Publishing.

Cronin, O., \& Gale, A. (1996). Photographs and the therapeutic process. Clinical Psychology Forum, 89, 24-28.

Darbyshire, P., Macdougall, C., \& Schiller, W. (2005). Multiple methods in qualitative research with children: More insight or just more? Qualitative Research, 5, 417-436.

Gallagher, M. (2006). Spaces of participation and inclusion? In E. K. M. Tisdall, J. M. Davis, M. Hill, \& A. Prout (Eds.), Children, young people and social inclusion: Participation for what? (pp. 159-178). Bristol: The Policy Press.

Garro, L. (2000). Remembering what one knows and the construction of the past: A comparison of cultural consensus theory and cultural schema theory. Ethos, 28, 275-319. 
Gaskell, G. (2002). Individual and group interviewing. In M. W. Bauer \& G. Gaskell (Eds.), Qualitative researching with text, image and sound (pp. 38-56). London: Sage.

Gerson, K., \& Horowitz, R. (2002). Observation and interviewing: Options and choices in qualitative research. In T. May (Ed.), Qualitative research in action (pp. 199-224). London: Sage.

Goodson, L., \& Phillimore, J. (2012). Community research: Opportunities and challenges. In L. Goodson \& J. Phillimore (Eds.), Community research for participation: From theory to method (pp. 3-20). Bristol: Policy Press.

Hammersley, M., \& Atkinson, P. (2007). Ethnography (3rd ed.). Abingdon: Routledge.

Harper, D. (1998). On the authority of the image: Visual methods at the crossroads. In N. Denzin \& Y. Lincoln (Eds.), Collecting and interpreting qualitative materials (pp. 130-149). Thousand Oaks, CA: Sage.

Harper, D. (2002). Talking about pictures: A case for photo-elicitation. Visual Studies, 17, 13-26.

Hunleth, J. (2011). Beyond on or with: Questioning power dynamics and knowledge production in 'child-oriented' research methodology. Childhood, 18, 81-93.

Johnson, K. (2008). Teaching children to use visual research methods. In P. Thomson (Ed.), Doing visual research with children and young people (pp. 77-94). Abingdon: Routledge.

Jordan, B., Redley, M., \& James, S. (1994). Putting the family first. London: UCL Press.

Kaplan, I. (2008). Being 'seen' being 'heard': Engaging with students on the margins of education through participatory photography. In P. Thomson (Ed.), Doing visual research with children and young people (pp. 175-191). Abingdon: Routledge.

Kara, H. (2015). Creative research methods in the social sciences: A practical guide. Bristol: Policy Press.

Klitzing, S. W. (2004). Women living in a homeless shelter: Stress, coping, and leisure. Journal of Leisure Research, 36, 483-513.

Loeffler, T.A. (2005). Looking deeply in: Using photo-elicitation to explore the meanings of outdoor education experiences. Journal of Experiential Education, 27, 343-346.

Lomax, H. (2012). Contested voices? Methodological tensions in creative visual research with children. International Journal of Social Research Methodology, 15, 105-117.

Luttrell, W. (2000). Good enough. Methods for Ethnographic Research, Harvard Educational Review, 70, $499-523$.

Luttrell, W. (2010). 'A camera is a big responsibility': A lens for analysing children's visual voices. Visual Studies, 25, 224-237.

Luttrell, W. (2013). Children's counter-narratives of care: Towards educational S. Children and Society, 27, $295-308$.

Mannay, D. (2015). Achieving respectable motherhood? Exploring the impossibility of feminist and egalitarian ideologies against the everyday realities of lived Welsh working-class femininities. Women's Studies International Forum, 53, 159-166.

Massey, D. (1995). The conceptualisation of place. In D. Massey \& P. Jess (Eds.), A place in the world? (pp. 45-86). Oxford: Oxford University Press/Open University.

Massey, D. (2005). For space. London: Sage.

Massey, D., \& Jess, P. (1995). Introduction. In D. Massey \& P. Jess (Eds.), A place in the world? (pp. 1-4). Oxford: Oxford University Press/Open University.

Middleton, D., \& Edwards, D. (1990). Conversational remembering: A social psychological approach. In D. Middleton \& D. Edwards (Eds.), Collective remembering (pp. 23-45). London: Sage.

Nind, M., Boorman, G., \& Clarke, G. (2012). Creating spaces to belong: listening to the voice of girls with behavioural, emotional and social difficulties through digital visual and narrative methods. International Journal of Inclusive Education, 16, 643-656.

Pimlott-Wilson, H. (2012). Visualising children's participation in research: Lego duplo, rainbows and clouds and moodboards. International Journal of Social Research Methodology, 15, 135-148.

Pink, S. (2007). Doing visual ethnography (2nd ed.). London: Sage.

Pink, S. (2009). Doing sensory ethnography. London: Sage.

Purcell, R. (2007). Images for change: Community development, community arts and photography. Community Development Journal, 44, 111-122.

Radley, A., \& Taylor, D. (2003a). Images of recovery: A photo-elicitation study on the hospital ward. Qualitative Health Research, 13, 77-99.

Radley, A., \& Taylor, D. (2003b). Remembering one's stay in hospital: A study in photography, recovery and forgetting. Health: An Interdisciplinary Journal for the Social Study of Health, Illness and Medicine, 7, 129-159.

Rose, G. (1995). Place and identity: A sense of place. In D. Massey \& P. Jess (Eds.), A place in the world? (pp. 87-132). Oxford: Oxford University Press/Open University.

Rose, G. (2012). Visual methodologies (3rd ed.). London: Sage.

Schratz, M., \& Steiner-Loffler, U. (2000). Pupils using photographs in school self-evaluation. In J. Prosser (Ed.), Imagebased research (pp. 209-224). London: Falmer Press.

Shohel, M. M. C. (2012). Nostalgia, transition and the school: An innovative approach of using photographic images as a visual method in educational research. International Journal of Research and Method in Education, 35, $269-292$.

Sorin, R., Brooks, T., \& Haring, U. (2012). Exploring children's environmental understandings through the arts. Creative Approaches to Research, 5, 15-31. 
Stedman, R. C. (2005). Resident-employed photography as a tool for understanding attachment to high amenity places. In G. P. Green, S. C. Deller, \& D. W. Marcouiller (Eds.), Amenities and rural development: Theory, methods, and public policy (pp. 197-215). Northhampton, MA: Edward Elgar.

Strack, R., Magill, C., \& McDonagh, K. (2004). Engaging youth through photovoice. Health Promotion Practice, 5, 49-58.

Thomson, P. (2008). Children and young people: Voices in visual research. In P. Thomson (Ed.), Doing visual research with children and young people (pp. 1-20). Abingdon: Routledge.

Van Auken, P. M., Frisvoll, S. J., \& Stewart, S. I. (2010). Visualising community: Using participant-driven photo-elicitation for research and application. Local Environment, 15, 373-388.

Wang, C., \& Burris, M. A. (1997). Photovoice: Concept, methodology, and use for participatory needs assessment. Health Education \& Behavior, 24, 369-387.

Wassenaar, D. (2006). Ethical issues in social science research. In M. Terre Blanche, K. Durrheim, \& D. Painter (Eds.). Research in practice: Allied methods for the social sciences (60-79). Cape Town: University of Cape Town Press.

Wells, L. (Ed.). (2000). Photography: A critical introduction. Abingdon: Routledge.

White, A., Bushkin, N., Carpena-Mendez, F., \& Laoire, C. N. (2010). Using visual methodologies to explore contemporary Irish childhoods. Qualitative Research, 10, 143-158. 